\title{
Transatlantica
}

Revue d'études américaines. American Studies Journal

\section{Introduction: The Poetics and Politics of Antiquity in the Long Nineteenth- Century}

\section{Ronan Ludot-Vlasak}

\section{(2) OpenEdition \\ Journals}

Electronic version

URL: https://journals.openedition.org/transatlantica/7830

DOI: $10.4000 /$ transatlantica. 7830

ISSN: $1765-2766$

\section{Publisher}

Association française d'Etudes Américaines (AFEA)

Electronic reference

Ronan Ludot-Vlasak, "Introduction: The Poetics and Politics of Antiquity in the Long Nineteenth-

Century", Transatlantica [Online], 2 | 2015, Online since 16 June 2016, connection on 31 January 2023. URL: http://journals.openedition.org/transatlantica/7830 ; DOI: https://doi.org/10.4000/transatlantica. 7830

This text was automatically generated on 31 January 2023.

\section{(†)

Creative Commons - Attribution-NonCommercial-NoDerivatives 4.0 International - CC BY-NC-ND 4.0 https://creativecommons.org/licenses/by-nc-nd/4.0/ 


\title{
Introduction: The Poetics and Politics of Antiquity in the Long Nineteenth- Century
}

\author{
Ronan Ludot-Vlasak
}

1 As Caroline Winterer argues in her insightful study of Greco-Roman culture in American intellectual life, "next to Christianity, the central intellectual project in America before the late nineteenth-century was classicism" (Winterer, 2002, 1). This permeation of ancient models in a new nation seeking to break from the yoke of European culture presents some paradoxes which have been pointed out by historian Meyer Reinhold:

Despite the distance from the great centers of humanistic learning, the absence of visible relics of the Greek and Roman presence to memorialize the continuity with classical antiquity and excite feelings of pride in the cultural heritage, and sporadic opposition on religious and utilitarian grounds, classical learning was swiftly naturalized on American soil, and in consequence a fair number of colonial and Revolutionary Americans were nurtured and molded by the humanistic tradition (Reinhold, 1984, 23).

Be it the name of certain institutions (the Senate) or their location (the Capitol), the influence of antiquity in early American art and architecture, the founding of cities named after ancient figures (Cincinnati), or the place of classics in college curricula, Greco-Roman antiquity was meant to provide the new nation with a set of political, aesthetic and philosophical models on the foundation of which its inhabitants might fulfil their destiny. Such ubiquity of (neo)classical culture led educated men and women in the late eighteenth century to speak of antiquity as a familiar world, to which they claimed to be the rightful heirs. Joseph Warren thus wore "a Ciceronian toga" in order to commemorate the Boston massacre in 1775 (Winterer, 2002, 26) and John Adams likened classical antiquity to a boudoir of octagonal shape with a "fulllength mirror on every side" in which the citizens of the New World might see their reflection (quoted in Shalev, 2009, 2). 
2 This fantasized connection to ancient cultures impacted Americans' understanding of historical time. In Rome Reborn on Western Shores, Eran Shalev has demonstrated that American history lent itself to typological readings and was often referred to as a reenactment of Greek and Roman annals. Antiquity was turned into both the birthplace of Western civilization and a horizon setting an example to be followed and improved by the emerging nation. Claiming continuity between the American experience and the classical world was also a way of downplaying the cultural ties which united the United States and Britain although these uses of antiquity were often mediated through eighteenth-century British appropriations of such models, the enduring presence of Addison's Cato in American revolutionaries' political imagination being a case in point (Shalev, 2009, 99-104).

3 Despite this "cult of antiquity" (Reinhold, 1984, 23), ancient cultures proved to be an ambivalent model at the turn of the nineteenth century. Athens' cultural legacy and Sparta's military ethos were praised, but references to the internecine conflicts which plagued ancient Greece were used by the Federalists as a warning against minimal government and Jefferson's political platform (Winterer, 2002, 20). ${ }^{1}$ Although republican Rome came to symbolize an ideal of civic and political virtue the citizens of the New World were to imitate and emulate, the Roman Empire was associated with debauchery and decadence; it provided them with "cautionary tales about civic virtue" (Winterer, 19) and held up a mirror of what the emerging nation might degenerate into, should it fail to fulfill the ideal it meant to embody.

Cultural historians have emphasized Americans' familiarity with the classics and shown how this cultural heritage informed their Weltanschauung as well as their conception of the United States' cultural and political identity. In Meyer Reinhold's words, "the authors of the classical canon offered the founders companionship, solace, and the models and antimodels which gave them a sense of identity and purpose" (Reinhold, 1984, 232). This issue of Transatlantica aims at accounting for the presence of antiquity in nineteenth-century America from a slightly different angle by questioning this alleged direct filiation with the Ancients. Central to all the articles is the subversive potential of literary imagination and its ability to question the apparent unity and familiarity of the classical models that shaped the American ethos. In this respect, it might be argued that revisiting classical antiquity enabled American writers to view the world in which they lived as "contemporaries" who "firmly h[e]ld [their] gaze on [their] own time so as to perceive not its light, but rather its darkness" (Agamben, 2009, 44). As the different contributors also show, the presence of classical antiquity in late eighteenth-century and nineteenth-century American literature may not be addressed exclusively in the light of the influence of the former on the latter; by unsettling dominant ideological constructs which sustained the reception of Greco-Roman cultures in the long nineteenth century, Mercy Otis Warren, Washington Irving, James Fenimore Cooper, Ralph Waldo Emerson, Margaret Fuller, Herman Melville, Emily Dickinson or Henry James unveiled the paradoxically heterogeneous and monumental nature of antiquity, thus offering new ways of apprehending it-an aspect which has so far attracted little critical attention in American literary studies.

5 Through the example of Mercy Otis Warren's remarkable appropriation of classical models, Eran Shalev sheds light on the ways in which American revolutionaries made classical Rome relevant to their political and national identity. Instead of staging Roman history by adapting it to late-eighteenth-century standards, Warren's plays 
"import[ed] Roman heroes into contemporary settings," conveying the illusion that America's revolutionary experience may easily bridge the historical and geographical gap between New England and the Roman Republic. Thirty years later, her Whig interpretation of early American history turned the Revolution into "a chapter in classical history." By "Romanizing" the United States, she transformed the classical heritage into a promise to be fulfilled on American shores. Yet her references to Roman annals also allowed her to expose the potential disruption of the classical ideals claimed by her contemporaries.

This ambivalent use of classical images and motifs is evidenced in early nineteenthcentury depictions of Native Americans. Likening them to Greco-Roman artefacts or historical figures may not be reduced to a legitimizing strategy that "elevates" the figure of the Indian. In Mark Niemeyer's words, it "contains various fundamental ambiguities at its very heart." The parallels drawn between Indian tribes and GrecoRoman cultures by William Tudor, Washington Irving, or James Fenimore Cooper may be read in relation to the trope of the "vanishing Indian" and obliquely hint at the potential violence and savagery of the classical world. Such associations undermine totalizing narratives that depicted ancient Greece and Rome as the cradle of Western civilization and question the United States' claim for this heritage.

7 Ralph Waldo Emerson's hermeneutics testifies to this ability for literature to rethink and reshape antiquity. The American philosopher challenged the historicity of the Bible while simultaneously drawing on the new perspectives offered by higher criticism, which no longer regarded the Bible as a book requiring no contextualization. Such new developments in biblical scholarship enabled Emerson to explore issues concerning the reading and legibility of texts and turned the exploration of the Ancient Near East into a textual and hermeneutic adventure-and the history of exegesis into "a narrative of emancipation." Although he considered that the Bible contained a universal truth, Emerson warned his reader that it may not be found in "the idoms of [Jesus'] language" or in the tropes in which it is cloaked. This is particularly visible in the philosopher's ambivalent attitude towards hieroglyphs and the historicity of the Holy Scriptures. This approach to antiquity ultimately suggests that biblical scholarship does not unveil the historical truth of ancient texts, but makes it possible for the scholar to explore the relevance of such writings to the present day. In such a line of interpretation, meaning may be accounted for in relation to the reader's experience, its "true location [...] ly[ing] not in the texts themselves, but in our ongoing dynamic exchanges with and about them."

Classical antiquity also manifests itself as a space of potentiality in the works Margaret Fuller published after her journey to Italy in 1847. Her discovery of the Eternal City filled her with enthusiasm and led her to write about Rome in utopian terms, which marked a significant change in her vision of both antiquity and utopias: up to that time, not only did she consider classical education to be a "dystopian intellectual environment" of female subjection to male power, but she was also skeptical of the utopian experiments launched by American transcendentalists in the early 1840 s. Leslie Eckel analyzes this evolution as a shift from "a space of local experience" to a "world of radical innocence." Fuller's transatlantic voyage from the New World to Old Europe ultimately challenges the pattern according to which American shores were the promised land onto which utopian dreams may be projected and turns Rome into a 
utopian space where neo-Platonic ideals and Europe's revolutionary present are merged.

9 As they revisit the world of the Ancients, both Fuller and Dickinson called into question the gendered performances at work in the cultural appropriations of antiquity. Instead of resorting to the classics as a familiar and reassuring set of models, Dickinson explored their subversive and liberating potential. Eric Athenot investigates the politics of such intertextual and intercultural practices. Far from being "an escapist strategy," allusions to ancient history and literature enabled Dickinson both to undermine patriarchal readings and appropriations of classical culture and to challenge slavery as well as teleological visions of history or Calvinistic tenets. Antiquity in her poems thus turns the "antique" world into an "antic" one.

Whereas the use of antiquity by Emerson, Fuller and Dickinson works as an empowering and liberating force, it may also prove to be an uncanny-if not threatening-space which disrupts identities and unveils destructive forms of violence. Stefano Evangelista's analysis of "The Last of the Valerii" not only explores the ways in which James "draws on archeology to investigate the relationship between the buried secrets of the soil and the hidden desire of the individual mind," but it also sheds light on the writer's ambivalent use of the archaeological fantastic, "La Vénus d'Ille" "function[ing] as a buried object from the literary past" both erased and brought to light in the short story.

11 Literary filiations and historical time are also questioned in Melville's late poetry. It is often assumed that Melville's verse on Greece is little more than a poetical transcript of the journal entries focusing on his Mediterranean journey in 1846-1847. Yet Bruno Monfort argues that such an approach overlooks the change of perspective one notices between the journal and "Syra." Although the poem resists Hellomaniac celebrations of Greek antiquity, it may not lend itself to a purely ironic reading concealing a thinlyveiled colonialist bias. On the contrary, the poetic voice frees itself from such depictions and "rescue[s the scene] from the picturesque." The allusion in the poem to a coin representing Proserpine blurs the line between the aesthetic and economic spheres, and the "spectacle of trade [paradoxically] leads to an ambiguous utopian time "when trade was not."

These seven essays contribute to our understanding of the modes through which the resurfacing of Greco-Roman culture in literary works questions this "sense of kinship with the ancients" (Richards, 1994, 8) as well as the aesthetic filiations between the new nation and its classical models. Instead of attesting to the use of stable and reliable cultural motifs, the circulation of classical antiquity in nineteenth-century American literature manifests itself as a complex intertextual and intercultural network challenging the Americans' claim for the classical heritage and contributes to shaping American literature as "a crisscrossing set of pathways, open-ended and ever multiplying, weaving in and out of other geographies, other languages and cultures" (Dimock, 2006, 3). As some of the articles demonstrate, the use of antiquity by Americans may not be reduced to a dual relationship, but requires many transatlantic detours: William Tudor's allusions to Apollo pass through Guido Reni's Aurora, Melville's mention of Proserpine is indebted to Winckelmann's History of Ancient Art, and Emerson's hermeneutics draws on nineteenth-century Near East archeology and philology. 
has been defamiliarized, the marmoreal antiquity celebrated by the champions of neoclassicism thus gives way to an unstable realm of experience and lets us glimpse at Greco-Roman cultures as a "multifaceted imaginary world" and "a dark continent to be explored, layer by layer"2" (Dupont, 2013, 287).

\section{BIBLIOGRAPHY}

AGAMBEN, Giorgio, "What is an apparatus?" and Other Essays, translated from Italian by David Kishik and Stefan Pedatella, Stanford, Stanford University Press, 2009.

DIMOCK, Wai Chee, Through Other Continents: American Literature across Deep Time, Princeton, Princeton University Press, 2006.

DUPONT, Florence, L'Antiquité, territoire des écarts. Entretiens avec Pauline Colonna d'Istria et Sylvie Taussig, Paris, Albin Michel, 2013.

HAMILTON, Alexander, James MADISON, and John JAY, The Federalist Papers, New York, Random House, 1982 [1787].

REINHOLD, Meyer, Classica Americana: The Greek and Roman Heritage in the United States, Detroit, Wayne State University, 1984.

RICHARD, Carl J., The Founders and the Classics: Greece, Rome, and the American Enlightenment, Cambridge, Harvard University Press, 1994.

SHALEV, Eran, Rome Reborn on Western Shores. Historical Imagination and the Creation of the American Republic, Charlottesville, London, University of Virginia Press, 2009.

WINTERER, Caroline, The Culture of Classicism: Ancient Greece and Rome in American Intellectual Life, 1780-1910, Baltimore, The Johns Hopkins University Press, 2002.

\section{NOTES}

1. This is for instance the case in Federalist Paper 9, in which Hamilton alludes to "the petty Republics of Greece" in order to convince his fellow citizens of "the utility of a confederacy" and of a "firm union" (Hamilton, Madison, Jay, 1982, 44, 46).

2. My translation. 


\section{AUTHOR}

RONAN LUDOT-VLASAK

Professeur

Université Lille 3-Charles de Gaulle

EA4074 CECILLE 